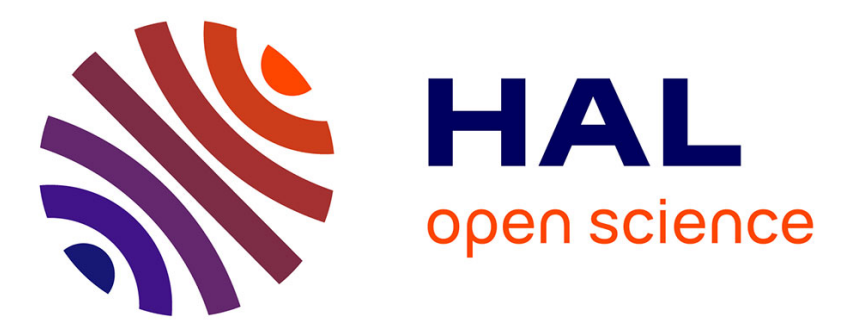

\title{
Enterocytin: A new specific enterocyte marker bearing a B30.2-like domain
}

\author{
Stephane Parnis, Cendrine Nicoletti, Vincent Ollendorff, Dominique \\ Massey-Harroche
}

\section{- To cite this version:}

Stephane Parnis, Cendrine Nicoletti, Vincent Ollendorff, Dominique Massey-Harroche. Enterocytin: A new specific enterocyte marker bearing a B30.2-like domain. Journal of Cellular Physiology, 2004, 198 (3), pp.441-451. 10.1002/jcp.10418 . hal-02680319

\section{HAL Id: hal-02680319 \\ https://hal.inrae.fr/hal-02680319}

Submitted on 31 May 2020

HAL is a multi-disciplinary open access archive for the deposit and dissemination of scientific research documents, whether they are published or not. The documents may come from teaching and research institutions in France or abroad, or from public or private research centers.
L'archive ouverte pluridisciplinaire HAL, est destinée au dépôt et à la diffusion de documents scientifiques de niveau recherche, publiés ou non, émanant des établissements d'enseignement et de recherche français ou étrangers, des laboratoires publics ou privés. 
FREE Webinar:

ClearLLab LS: A New CE-IVD Orientation

Tube to Guide You Through Diagnosis

of Hematolymphoid Malignancies

Dr. Katherina Psarra from the Immunology Dept. at Evangelismos Hospital, Athens and Dr. Michael Kapinsky, one of Beckman Coulter's clinical flow cytometry experts, will present:

- Determination of immunologically defined leukocyte subpopulations

- Immunophenotyping of hematological malignancies

- Influence of instrument and dye performance characteristics on your phenotyping results

- Panel design driven by: dye brightness vs antigen density; spillover-spreading and co-expression patterns

\section{Thursday | July 12, 2018 3pm CEST | 9 am EDT}

Receive a FREE eCasebook when you Register Here 


\title{
Enterocytin: A New Specific Enterocyte Marker Bearing a B30.2-Like Domain
}

\author{
STÉPHANE PARNIS, CENDRINE NICOLETTI, VINCENT OLLENDORFF, \\ AND DOMINIQUE MASSEY-HARROCHE* \\ Institut Méditerranéen de Recherche en Nutrition, Faculté des Sciences de \\ Saint Jérôme, Avenue Escadrille Normandie-Niemen, Marseille cedex, France
}

\begin{abstract}
Enterocyte differentiation is correlated to the expression of specific proteins which only a few of them are identified. In this study, we characterize a new marker of enterocyte differentiation using monoclonal antibodies. We showed that small intestinal enterocytes specifically express a new $47 \mathrm{kDa}$ protein named Enterocytin. Expression of this protein increase along the crypt-villus axis and it is concentrated in the terminal web, lateral plasma membrane domain, and nucleus membrane of mature enterocytes. A 1.8-kb cDNA of Enterocytin was isolated by expression cloning from a cDNA library of rabbit small intestine. The amino acid sequence obtained shows an N-terminal region with a coiled-coil structure and a B30.2-like domain in the C-terminus region. By co-transfection and immunoprecipitation procedures on Cos cells, it was observed that the coiled-coil domain is involved in the homodimerization of Enterocytin. In the human intestine, a similar $47 \mathrm{kDa}$ protein was detected, exclusively in the small intestinal enterocytes. In addition, expression of this protein in Caco2 cells is correlated with the state of differentiation of these cells. The restricted expression of Enterocytin in the intestine and its localization in mature cells suggest that it may contribute to the differentiation processes and maintenance of the enterocytic polarity. J. Cell. Physiol. 198: 441 451, 2004. () 2003 Wiley-Liss, Inc.
\end{abstract}

The intestine shows two axes of cellular differentiation: on one hand, the horizontal rostrocaudal axis, where specialization results in the small intestine and colon, and on an other hand, the vertical axis where specialization occurs in crypto-villi for the small intestine or in crypto-plateau for the colon. Cell differentiation occurs during embryogenesis and postnatal period until weaning on the rostrocaudal axis (Calvert and Pothier, 1990), whereas this process is a fast and permanent one along the vertical axis (Booth and Potten, 2000; Wong et al., 2000; Marshman et al., 2002). The vertical differentiation begins near the bottom of the crypts, where stem cells proliferate, and continues during cell migration toward the tips of villi in the small intestine or plateau in the colon. This differentiation process generates three epithelial lineages: absorptive cells (called enterocytes in the small intestine and colonocytes in the colon), mucus-producing goblet cells and enteroendocrine cells (Wong et al., 2000). The process of cell differentiation along these horizontal and vertical intestinal axes seems to be at least partly controlled and maintained by homeobox genes $C D X$ (Clatworthy and Subramanian, 2001). Many results have showed that the caudal-related $C d x-1$ and $C d x-2$ homeobox genes play a major role in intestinal development and in the control of intestinal cell proliferation, differentiation, and identity (Freund et al., 1998; Beck, 2002).

Absorptive cells account for $85 \%$ of all the epithelial cells located along the intestine, and are characterized by abundant plasma membrane apical extensions, or microvilli, which increase the absorption area. These microvilli have the same width, whereas the length varies with the intestinal region. In a single cell, the homogeneous size of the microvilli gives to the apical cell domain a brush border appearance. The terminal web region contains an elaborate cytoskeleton, which supports the apical microvillar cytoskeleton and is therefore involved in the organization of the apical pole (Salas et al., 1997).

One of the markers which can be used to characterize the brush border cytoskeleton is villin (Friederich et al., 1990; Athman et al., 2002), an actin-binding protein expressed by epithelial cells with a brush border structure, such as those in the gastrointestinal, urogenital, and respiratory tracts (Pringault et al., 1991). Although they all have a common structure, these epithelial cells have characteristic functions reflected in the specific protein content of their plasma membrane domains (Kawai et al., 1974; Christiansen and Carlsen,

*Correspondence to: Dominique Massey-Harroche, Faculté des Sciences de Saint Jérôme, IMRN, INRA-UMR 1111, Avenue Escadrille Normandie-Niemen, 13397 Marseille cedex 20, France. E-mail: dominique.massey-harroche@univ.u-3mrs.fr

Received 19 May 2003; Accepted 29 July 2003

DOI: $10.1002 / j c p .10418$ 
1981; Kenny and Maroux, 1982; Gorvel et al., 1988). However, only a few of these proteins, characterized so far have led to the unambigous identification of a single cellular phenotype such as the terminal differentiated enterocyte. Mature enterocytes are specialized in digestion and the absorption of nutrients. The fact that digestive enzymes constitute the main class of glycoproteins in the brush border membrane reflects this specificity. Colonocytes are specialized in the absorption and secretion of electrolytes and their brush border membrane contains many transporters (Rajendran and Binder, 2000). However, the identification of specific proteins exclusively expressed by enterocytes is limited to a small number, such as sucrase-isomaltase (Galand, 1989), lactase-phlorizin hydrolase (Naim, 2001), IFABP (Hertzel and Bernlohr, 2000; Storch and Thumser, 2000).

The aim of the present study was to characterize some new markers of enterocyte differentiation. We have identified a new protein bearing a B30.2-like domain (Henry et al., 1998). Mutations within the B30.2-like domain of the pyrin (also known as marenostrin) and MID 1 are responsible for familial Mediterranean fever (FMF) and Opitz syndrome, respectively, highlighting the biological importance of this domain (Quaderi et al., 1997; Cox et al., 2000). In this article, we describe the subcellular distribution of this new enterocytic marker and some of its structural characteristics.

\section{MATERIALS AND METHODS Obtaining monoclonal antibodies}

E6.1 monoclonal antibody (mAb). To obtain monoclonal antibodies with which to label the subcellular compartments of small intestinal epithelial cells, two Balb/c mice were immunized with a crude preparation of endoplasmic reticulum (ER) obtained from rabbit enterocytes (Moktari et al., 1986). This ER suspension contained $10 \mathrm{mg}$ protein per ml PBS. The program of immunization was as follows (with respect to the day of fusion: $\mathrm{dO}$ ), $\mathrm{d} 55$ and $\mathrm{d} 41,75 \mu \mathrm{l}$ of the ER preparation plus $75 \mu \mathrm{l}$ of Freund's complete adjuvant were injected intraperitoneally (i.p.); d27 and d14, $150 \mu \mathrm{l}$ without adjuvant was injected i.p.; d3 mice were intravenously injected (i.v.) with $150 \mu \mathrm{l}$ of ER suspension. Fusion was performed as described in Gorvel et al. (1986). One hundred ten hybridomas were detected and tested by performing indirect immunofluorescence labeling on frozen sections of rabbit jejunum (see below). Hybridoma E6.1 secreted an antibody that reacted specifically with enterocytic cells. This E6.1 mAb is an IgG.

2C5 mAb. 2C5 mAb was obtained by immunizing one Lou rat with denatured $47 \mathrm{kDa}$ protein immunoprecipitated by E6.1 mAb (see below, in the "immunoprecipitate"). The immunoprecipitate was subjected to SDSPAGE electrophoresis through polyacrylamide gels. The band corresponding to the $47 \mathrm{kD}$ a protein was cut off and then crushed before the injection was performed. We estimated at $25 \mu \mathrm{g}$ the quantity of protein injected at each immunization step. The Lou rat immunization schedule previously described in Massey et al. (1991) was adopted here. The $2 \mathrm{C} 5 \mathrm{mAb}$ was selected on the basis of Western-blot reactions with $30 \mu \mathrm{g}$ of rabbit intestinal homogenate and $10 \mu \mathrm{g}$ of Cos cell extract, transfected with Myc-Enterocytin.

\section{Immunofluorescence}

The immunofluorescence procedure was performed as described by Feracci et al. (1982). For immunofluorescence reactions, the E6.1 or 2C5 monoclonal antibodies present in the culture supernatant and commercial fluorescein derivatives of anti-mouse or anti-rat immunoglobulin diluted to 1:200 were used. The dilutions and various washes were carried out with $10 \%$ fetal calf serum in phosphate buffer. Immunofluorescence reactions were carried out at room temperature for $45 \mathrm{~min}$ at each incubation. After the last wash, sections were mounted with Vectashield (Vector laboratories, Burlingame, CA). Epifluorescence was performed with a Leitz DMRB microscope (Leica, Heerbrugg, Switzerland) equipped with a Leica wild MPS52 photoautomat photography system using $40 \times(1-0.5)$ infinity-corrected objectives. TMax 400 ASA films were used for the photography.

\section{Sources of human tissues}

Human jejunum and colon samples were obtained, from the extremities of surgical resections of isolated cancerous tumor in the caudal part of the duodenum and colorectal cancer, respectively. These tissues were found to be normal upon histological examination.

\section{Tissue preparation and dot-blot analysis}

Rabbit organs were dissected out and immediately frozen at $-80^{\circ} \mathrm{C}$. The mucosa of the small intestine and the colon were scraped before being frozen, and the muscular and serosal tissues were discarded. One gram of each tissue was disrupted with five strokes of a Thomas potter at $3,000 \mathrm{rpm}$ in $8 \mathrm{ml}$ of $0.25 \mathrm{M}$ sucrose, $10 \mathrm{mM} \mathrm{KCl}, 1 \mathrm{mM} \mathrm{MgCl} 2$, and $10 \mathrm{mM}$ Tris-HCl buffer pH 7.3 containing $1 \mathrm{mM}$ phenyl-methyl sulfonyl fluoride (PMSF), $1 \mathrm{mM}$ benzamidine, $2 \mathrm{mM} \beta$-phenyl propionate, $1 \mu \mathrm{g} / \mathrm{ml}$ of leupeptin, and $0.1 \mu \mathrm{g} / \mathrm{ml}$ of ovomucoid. Prior to the dot-blot procedure, the homogenate was centrifuged at $27,000 \mathrm{rpm}$ in a $35 \mathrm{Ti}$ rotor for $1.5 \mathrm{~h}$ to separate the soluble material from that bound to membranes. Pellets from $1 \mathrm{~g}$ of tissue were suspended in $3 \mathrm{ml}$ of homogenization buffer. Samples containing $10 \mu \mathrm{g}$ of protein were deposited on nitrocellulose membrane and subjected to immunodot analysis.

\section{Immunoprecipitation and immunoblotting experiments}

Immunoprecipitation by E6.1 mAb. A rat mAb against the K chain of mouse IgG, the $1395211 \mathrm{mAb}$ (Immunotech, Marseille, France), was coupled to AffiGel 10 (Bio-Rad, Hercules, CA) as recommended by the manufacturer. The immunogel obtained was then incubated for $2 \mathrm{~h}$ with a large excess of $\mathrm{E} 6.1 \mathrm{mAb}$ in culture supernatant. The E6.1 beads obtained were used for the immunoprecipitation of the antigen recognized, as described by Massey et al. (1987).

Immunoprecipitation with 9E10 anti-Myc mAb. Cos-1 transfected with Myc-Enterocytin cDNAs were washed in cold PBS and lysed in a lysis buffer $(20 \mathrm{mM}$ Tris $\mathrm{pH} 7.6,150 \mathrm{mM} \mathrm{NaCl}, 1.5 \mathrm{mM} \mathrm{MgCl}_{2}, 1 \mathrm{mM}$ EGTA, $10 \%$ glycerol, and $1 \%$ Triton X-100) supplemented with $1 \mathrm{mM}$ PMSF, $10 \mu \mathrm{g} / \mathrm{ml}$ leupeptin, and $1 \mathrm{mM}$ benzamidin. Lysates were cleared by centrifugation and subjected either to Western-blot analysis or to immunoprecipi- 
tation. Prior to the immunoprecipitation procedure, lysates were incubated with anti-myc $9 \mathrm{E} 10 \mathrm{mAb}$ for $4 \mathrm{~h}$ at $4{ }^{\circ} \mathrm{C}$. Protein A-agarose was added, and immune complexes bound to beads were recovered after $1 \mathrm{~h}$, washed three times with lysis buffer, and treated as mentioned below.

Immunoblotting experiments. Immunoprecipitates were treated as described by Green et al. (1981) and loaded on SDS-PAGE with $12 \%$ polyacrylamide slab gel as described by Laemmli (1970). The immunoblotting procedure used has been described elsewhere (Feracci et al., 1985).

\section{cDNA library construction and screening}

Rabbit intestinal mucosa cDNA library was constructed in $\lambda$ ZAP II vector using $11.5 \mu \mathrm{g}$ of polyadenylated RNA from rabbit jejunum mucosa according to the manufacturer's instructions (ZAP cDNA Synthesis kit, Stratagene, Europe, Netherlands). The library was packaged into phage particles using the Gigapack II System (Stratagene) and amplified once in XL1-Blue MRF' Escherichia coli (Stratagene). In order to perform immunological screening, the library was plated on XL1-Blue MRF' $E$. coli, and replicas were obtained by applying nitrocellulose membranes (PROTRAN, Schleicher \& Schuell, France). Immunodetection was performed with the mAb E6.1 described above and an anti-mouse immunoglobulin G conjugated with horseradish peroxidase. Positive clones were purified in three runs and recovered in the form of Bluescript plasmids by performing in vivo excision using ExAssist helper phage and SORL E. coli (Stratagene).

\section{Single strand biotinylated Enterocytin probe and Northern blot}

A $3^{\prime}$ Enterocytin probe (676 bp) was obtained by digesting the clone with EcoO109I and subcloning the fragment into bluescript KS plasmid (Stratagene). The probe was labeled with biotinylated $r$-UTP by means of the T7 extension primer using the RNA Transcription kit from Stratagene. To isolate the RNA, the kidney and mucosa from the jejunum and colon were cut off under Rnase-free conditions. Total RNA was extracted from tissues using an RNA isolation kit from Stratagene. Poly (A)-containing RNA was isolated by performing chromatography on oligo(dT) cellulose according to the manufacturer's instructions (Poly (A) Quick mRNA Isolation kit, Stratagene). Prior to the Northern blotting procedure, $10 \mu \mathrm{g}$ of total RNA were separated on a $0.9 \%$ agarose gel containing $5.4 \%$ formaldehyde and transferred in $10 \times \mathrm{SSC}\left(3 \mathrm{M} \mathrm{NaCl}, 0.3 \mathrm{M} \mathrm{C}_{6} \mathrm{H}_{5} \mathrm{Na}_{3} \mathrm{O}_{7} \mathrm{pH}\right.$ 7) to hybond $\mathrm{N}+$ nitrocellulose membrane (Amersham, Biosciences, France). Membrane containing RNA was hybridized with the biotinylated Enterocytin probe for $16 \mathrm{~h}$ at $68^{\circ} \mathrm{C}$, rinsed with revelation buffer for $5 \mathrm{~min}$, and saturated for $30 \mathrm{~min}$ with blocking reagent from Boehringer Mannheim, France. Revelation was performed with streptavidin conjugated with alkaline phosphatase (Boehringer Mannheim) and its chemio-luminescent substrate (CSPD, Disodium 3-(4-meth-oxyspiro\{1, 2dioxetane-3, $2^{\prime}$-(5'-chloro) tricyclo [3.3.1.1 $\left.{ }^{3,7}\right]$ decan $\}-4$ yl) phenyl phosphate, Boehringer Mannheim) and the membrane was autoradiographed on Kodabrome II RC films (Kodak-Pathé, France).

\section{Plasmid constructions}

The Myc-tagged constructs were made using the Prk5myc vector (Borg et al., 1996). Myc-tagged total Enterocytin was obtained in two steps. First, the partial Enterocytin cDNA (an $856 \mathrm{bp} \mathrm{5}$-fragment) from the methionine codon to the $B g l \mathrm{II}$ restriction site was obtained by polymerase chain reaction and inserted into a prK5myc vector containing a CMV promoter. The total Enterocytin coding cDNA was obtained by ligating the $3^{\prime}$ remaining fragment generated by $B g l \mathrm{II} / \mathrm{XhoI}$ double digestion from the pbluescript plasmid containing Enterocytin cDNA. Myc-tagged partial Enterocytin constructs, encoding coiled-coil or B30.2 domains of the Enterocytin, were obtained by PCR and subcloned into prK5myc vector at the Bam HI and EcoRI restriction sites. The GFP-tagged (GFP fused to the $\mathrm{N}$ terminus of the targeted protein) construct was made using the pEGFP-C1 vector (ClonTech Laboratories, Palo Alto, CA). EGFP-Enterocytin was created by subcloning fulllength rabbit Enterocytin cDNA into the BglII and HindIII sites of pEGFP-C1.

\section{Cell cultures and transfection}

Cos- 1 cells were grown in $35 \mathrm{~mm}$ dishes, in $5 \% \mathrm{CO}_{2}$ at $37^{\circ} \mathrm{C}$ in Dulbecco's modified Eagle's medium supplemented with $10 \%$ fetal bovine serum. Cells were transiently transfected using a lipid based composition (FUGENE $^{\text {TM }}$ six transfection reagent, Roche Diagnostic, France) according to the manufacturer's instructions. Cells were plated at $1.4 \times 10^{4}$ cells $/ \mathrm{cm}^{2}$. Fluorescence and immunoprecipitation experiments were performed 24 and $48 \mathrm{~h}$ after transfection, respectively.

\section{cDNA sequence}

cDNA clones were fully sequenced on both strands by Genome express (Meylan, France). The Enterocytin cDNA sequence was submitted to GenBank under accession number: AY079123.

\section{Sequence analysis and phylogenetic tree}

The nucleotide sequence and the deduced amino acid sequence were analyzed by comparing them with the GenBank database, using the BLASTN and BLASTX network servers at the National Center for Biotechnology Information. Alignment amino acid sequences were performed using the Clustalw1.8 PC software program (Thompson et al., 1994). Phylogenetic and molecular evolutionary analyses were conducted using MEGA version 2.1 (Kumar et al., 2001) and constructed using the neighbour-joining method (Saitou and Nei, 1987).

\section{Tissue distribution of E6.1 antigen}

Immunodot analysis of homogenates from various tissues (Fig. 1A) show that the E6.1 mAb reacts only with homogenates from duodenum, jejunum, and ileum mucosa, the most intense signal being that obtained with jejunum mucosa. The very light reaction of the liver, pancreas, colon, smooth muscle, and lung are the same when E6.1 is omitted suggesting a nonspecific binding of the peroxidase anti-mouse antiserum (data not shown). In addition, when E6.1 mAb is used for the immunolabeling of frozen sections of various tissues 
A

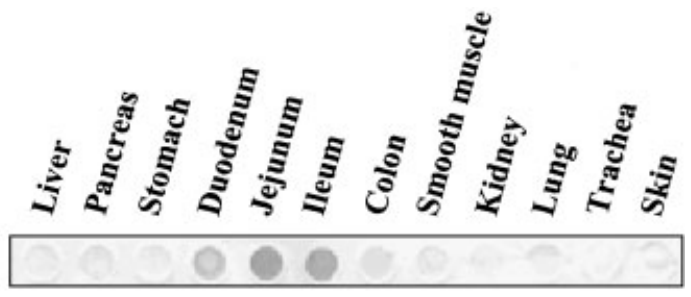

B
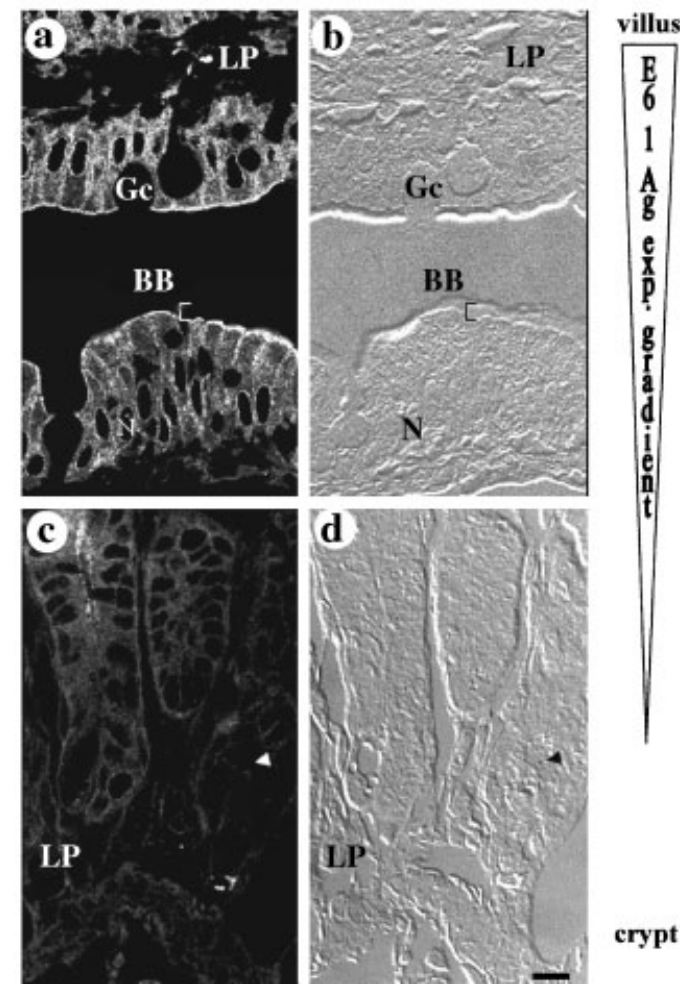

Fig. 1. A: Rabbit tissue distribution of E6.1 Ag with E6.1 monoclonal antibody $(\mathrm{mAb})$ based on dot analysis. For each tissue, $40 \mu \mathrm{g}$ of proteins were deposited. B: Pattern of immunolabeling obtained with E6.1 mAb on thin frozen sections of rabbit jejunum. a, b: Section of jejunal villi. c, d: Section of a crypt region of jejunum. $b$ and $d$ are the Nomarski views of the same field as in a and c, respectively. LP, lamina propria; Gc, goblet cell; $\mathrm{BB}$, brush border; $\mathrm{N}$, nucleus; arrowheads indicate a lower crypt not labeled by E6.1 mAb. Scale bars $=10 \mu \mathrm{m}$

such as the kidney, the lung, the muscle, and the gastrointestinal tract and associated glandular tissues, a reaction is detected in only one type of cell: enterocytes, the absorbent cells of the small intestine (Fig. 1B). In these cells, E6.1 mAb labels the terminal web area, the lateral plasma membrane domain and the nuclear membrane, as can be seen in the longitudinal villar section (Fig. 1B, a).

The increasing gradient in the pattern of E6.1 mAb labeling along the crypt-villus axis can be clearly observed in Figure 1B. In villus mature enterocytes, the terminal web, the lateral and nuclear membranes are labeled while in the upper crypts, only the terminal web is labeled, and in the deepest crypts (indicated by an arrowhead in Fig. 1B, c), no specific structures are recognized by the antibody. The localization and expression of E6.1 antigen seems to depend on the state of enterocytic differentiation.

\section{Immunoprecipitation of E6.1 Ag}

We performed immunoprecipitation experiments to further characterize E6.1 Ag. The membrane and cytosoluble characteristics of E6.1 Ag were determined by testing its presence using immunodot procedures in the soluble and particulate fractions separated from the intestinal homogenate by high speed centrifugation. All the immuno-reactive material is found to be in the particulate fraction (data not shown), which suggests that E6.1 Ag is associated with membranes and/or the cytoskeleton. This is consistent with the localization determined by immunofluorescence. The particulate fraction was subjected to Triton X-100 solubilization. As shown in Figure 2, E6.1 mAb immunoprecipitates only one protein with a molecular weight of approximately $47 \mathrm{kDa}$ from the soluble detergent supernatant (Fig. 2A, E6.1 I.P. revealed by coomassie blue). The fact that no $\mathrm{N}$-terminal amino acid sequences were obtained upon performing Edman degradation assays with the immunoprecipitated protein suggests that its $\mathrm{NH}_{2}$ terminal is blocked.

\section{Production and characterization of a secondary mAb: $2 \mathrm{C5} \mathbf{m A b}$}

Since E6.1 mAb does not recognize any proteins in the Western blotting experiments, we used the $47 \mathrm{kDa}$ protein immunoprecipitated by E6.1 $\mathrm{mAb}$ as an immunogen to produce a secondary $\mathrm{mAb}$ that could be used in a Western-blot. The mAb obtained (2C5 mAb) shows the $47 \mathrm{kDa}$ protein immunoprecipitated by E6.1 mAb (Fig. 2A), as well as a diffuse band at about $35 \mathrm{kDa}$. The $\mathrm{NH}_{2}$ terminal of this $35 \mathrm{kDa}$ protein is also blocked then we identified it by mass spectrometry, more than $27 \%$ of trypsic peptides was identical to those obtained with immunoprecipitated $47 \mathrm{kDa}$ protein (data not shown) (Wilm, 2000). We can conclude that this band is due to hydrolysis occurring during the solubilization of particulate fraction, since $2 \mathrm{C} 5 \mathrm{mAb}$ recognizes only one band at $47 \mathrm{kDa}$ among all the proteins of rabbit small intestinal homogenate (Fig. 2A).

In rabbit, as shown in Figure 2B, the Western blotting procedure with $2 \mathrm{C} 5 \mathrm{mAb}$, detects the $47 \mathrm{kDa}$ protein only in the duodenum, jejunum, and ileum. By immunolabeling, 2C5 mAb reacts exclusively, like E6.1 mAb, with enterocytes, but the labeling is restricted to the terminal web, as shown in Figure 2C. In addition, we also observe with $2 \mathrm{C} 5 \mathrm{mAb}$ a positive gradient of expression along the crypto-villi axis. These results strongly suggest that E6.1 and 2C5 mAbs recognize the same $47 \mathrm{kDa}$ protein and only this protein.

In contrast with $\mathrm{E} 6.1 \mathrm{mAb}$ that does not recognize any human antigens, $2 \mathrm{C} 5 \mathrm{mAb}$ detects a $47 \mathrm{kDa}$ protein by Western-blot analysis in human jejunum, Caco2 cells but not in human colon (Fig. 3A).

We observe, by immunofluorescence on human intestinal sections, the same localization as in the rabbit (Fig. 3B). Only terminal web of human enterocytes is recognized in the small intestine whereas the colon is 

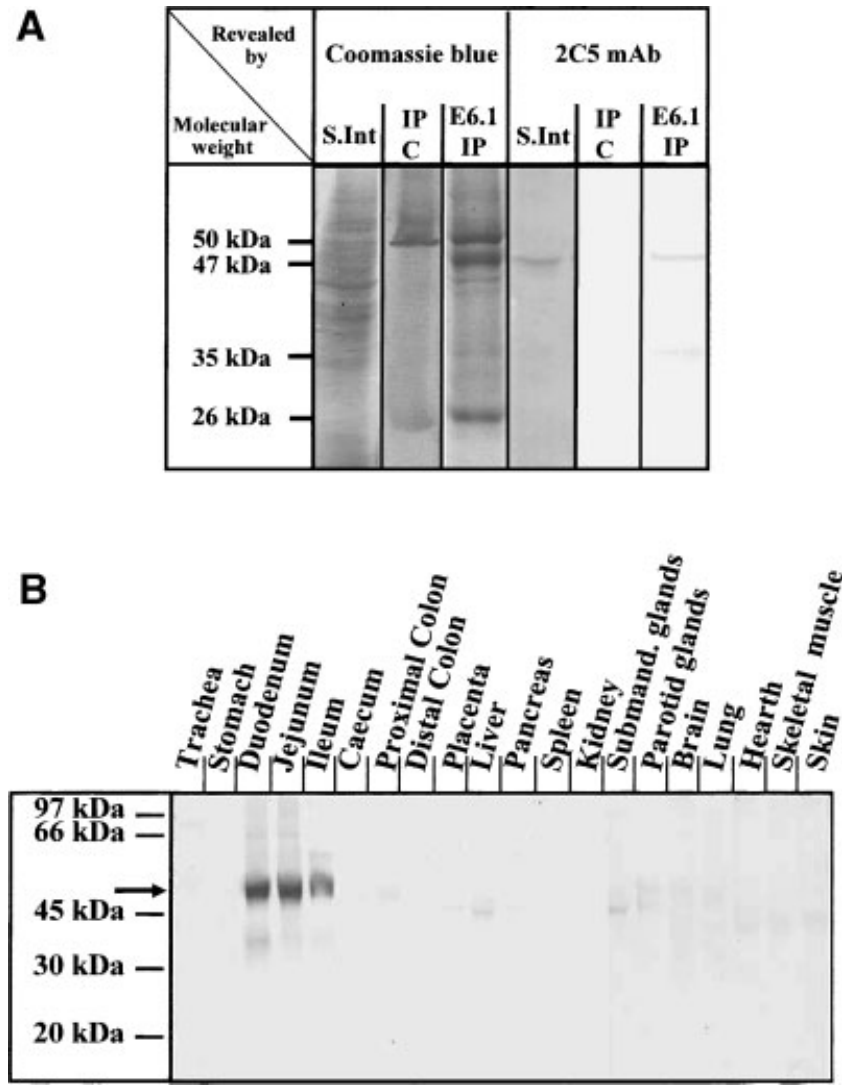

Fig. 2. A: Identification of rabbit E6.1 Ag immunoprecipitated by E6.1 mAb and characterization of $2 \mathrm{C} 5 \mathrm{mAb}$. Total proteins from rabbit small intestinal mucosa (S. Int.) and protein immunoprecipitated by E6.1 mAb from Triton extract of mucosal homogenate (E6.1 IP) were separated by SDS-PAGE and revealed as indicated using either Coomassie blue or 2C5 mAb immunostaining procedures after transferring the proteins onto nitrocellulose. IPC corresponds to an immunoabsorbent not incubated with homogenate extract: The 50 and $25 \mathrm{kDa}$ bands correspond to the heavy and light chains of

not labeled. The presence of this protein was also detected in Caco2 cells. These cells, originated from a human colon carcinoma, spontaneously undergo a process of enterocytic differentiation after reaching confluence in culture (Chantret et al., 1988). This differentiation is characterized by the polarization of the cell layer, the formation of domes, and the presence of an apical brush border membrane containing hydrolases such as sucrase-isomaltase and dipeptidylpeptidase IV. Immunolabeling with 2C5 mAb in Caco2 cells differs according to the differentiation status: at confluence, we observe a weak basal diffuse labeling in the cytoplasm (Fig. 3B, c) whereas, 4 days (Fig. 3B, e) or 7 days after confluence the labeling strongly increases and concentrates at the terminal web of $\mathrm{CaCo} 2$ cells.

In view of the tissue distribution and the immunofluorescence experiments, we can state that only enterocytes express the $47 \mathrm{kDa}$ protein recognized by E6.1 and $2 \mathrm{C} 5 \mathrm{mAbs}$. It is therefore proposed to name this protein enterocytin, to highlight its enterocytic specificity.
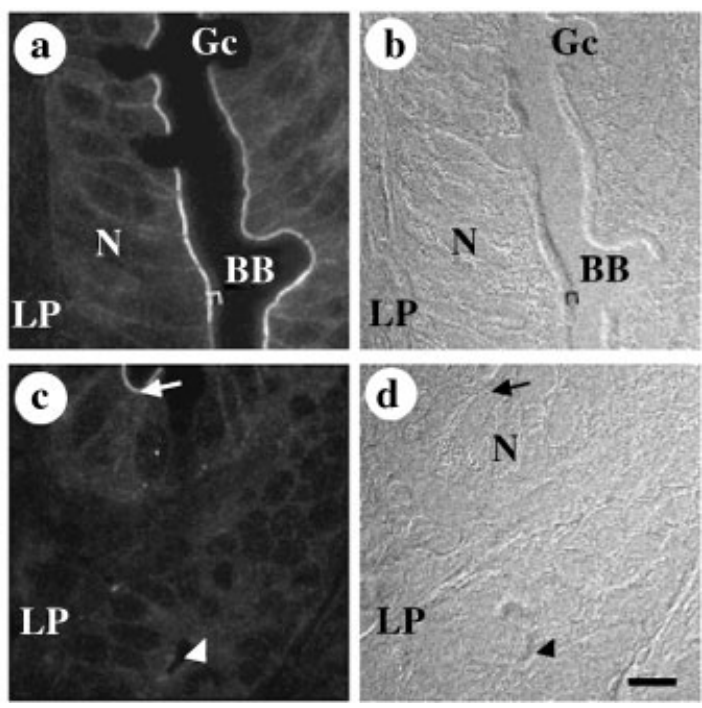

immunoadsorbent. B: Rabbit tissue distribution of 2C5 Ag with 2C5 $\mathrm{mAb}$ by Western-blot analysis. For each tissue, $40 \mu \mathrm{g}$ of proteins were loaded. C: Pattern of immunolabeling obtained with $2 \mathrm{C} 5 \mathrm{mAb}$ of thin frozen sections of rabbit. $\mathbf{a}, \mathbf{b}$ : Section of rabbit jejunal villi. c, d: Section of a crypt region of rabbit jejunum. $b$ and $d$ are Nomarski views of the same field as in a and c, respectively. Gc, goblet cell; BB, brush border; LP, lamina propria; N, nucleus; arrowheads indicate a lower crypt not labeled with $2 \mathrm{C} 5 \mathrm{mAb}$, and arrows indicate a higher site on the crypto-villus axis labeled with $2 \mathrm{C} 5 \mathrm{mAb}$. Scale bars $=10 \mu \mathrm{m}$.

\section{Cloning, nucleotide sequence, and identification of Enterocytin mRNA}

To identify the cDNA coding for the enterocytin, a $\lambda$ ZAP II rabbit intestinal expression cDNA library was screened with E6.1 mAb. Two positive clones with cDNA inserts $1.8 \mathrm{~kb}$ long were isolated and sequenced. Both have the same 1,852 bp nucleotide sequence (GenBank accession number AY079123). Analysis of the sequence shows the presence of an 85-nucleotide $5^{\prime}$ untranslated region (UTR) followed by a 1,191 nucleotides long open reading frame (position $86-1,279$ ), a 573 nucleotides $3^{\prime}$ UTR, and a poly (A) tail. This cDNA is probably a fulllength cDNA, as indicated by the presence of a stop codon upstream of the ATG codon, at the 8th nucleotide position. Furthermore, a $676 \mathrm{bp}$ probe located in the $3^{\prime}$ region (from 1,172 to $1,852 \mathrm{bp}$ ) was used in Northern blotting analysis with RNA isolated from the small intestine, colon, and kidney. These three organs contain absorptive cells with a similar apical structure, having a 
A

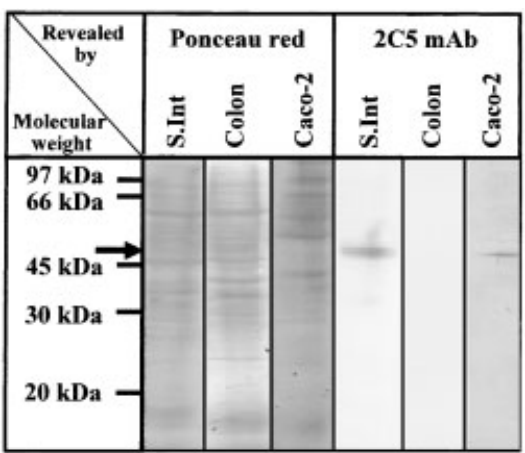

B
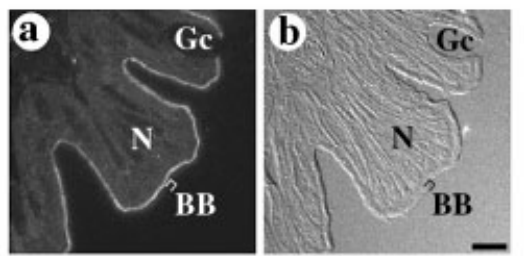

Human Villi
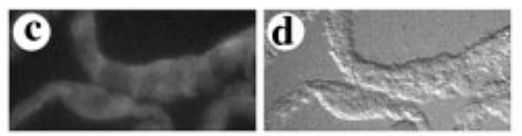

Confluence (day O)

Post-confluence (day 4)
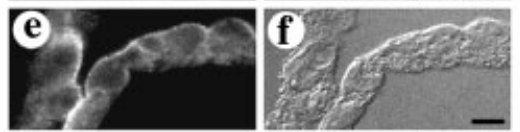

Caco-2 cells jejunum

Fig. 3. A: Distribution of $2 \mathrm{C} 5 \mathrm{Ag}$ in human intestinal tissues and Caco2 cells. Proteins from S. Int. and colon mucosa $(40 \mu \mathrm{g} / \mathrm{lane})$ or from Caco2 cells $\left(7 \times 10^{4}\right.$ cells/lane) were separated by SDS-PAGE and revealed as indicated using either Ponceau red or $2 \mathrm{C} 5 \mathrm{mAb}$ immunostaining after transfer onto nitrocellulose. B: Pattern of immunolabeling obtained with $2 \mathrm{C} 5 \mathrm{mAb}$ of thin frozen sections of human jejunal villi (a) and Caco2 cells (c, e). c: Caco2 cells in the confluence state (day 0). e: Caco2 cells in the postconfluence state (day 4). $\mathbf{b}, \mathbf{d}$, and $\mathbf{f}$ are Nomarski views of the same field as in a, c, and e, respectively. Gc, goblet cell; BB, brush border; N, nucleus. Scale bars $=10 \mu \mathrm{m}$

terminal web and a brush border. Among these tissues, only one transcript approximately $1.8 \mathrm{~kb}$ long was identified exclusively in the small intestine: this length corresponds to that of the isolated cDNA clone (Fig. 4).

\section{Enterocytin amino acid sequence and homology analysis}

The cloned cDNA encodes for a protein of 397 amino acids long with a putative $\mathrm{Pi}$ of 6.15 and a calculated molecular weight of $46,997 \mathrm{Da}$, which is consistent with the size of the protein immunoprecipitated by E6.1 mAb. Neither a signal peptide sequence nor a transmembrane domain are detected in the polypeptide. This protein consists of two regions: a coiled-coil $\mathrm{N}$-terminal region and a B30.2-like C-terminus domain (Fig. 5A).

Using a statistical coiled-coil prediction program (Combet et al., 2000), the $\mathrm{N}$-terminal region was found to have a high probability of forming a coiled-coil configuration consisting of 26 heptad repeats: 6 from residues His 13 to Glu 54 and 20 from Pro 69 to Leu 208. The helical wheel of this coiled-coil structure is pre-

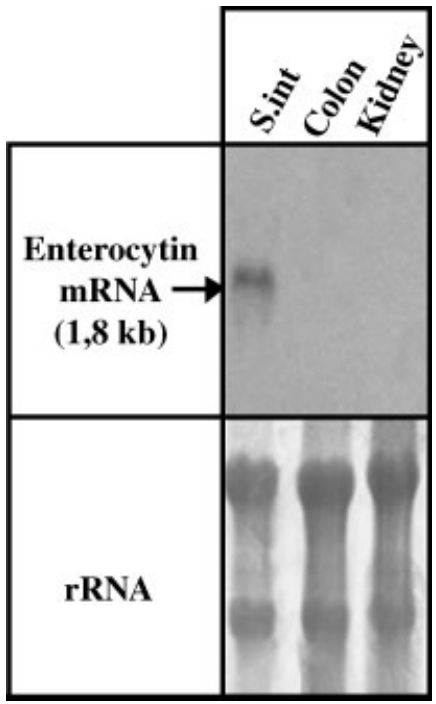

Fig. 4. Northern blot analysis with $10 \mu \mathrm{g}$ total RNA of the rabbit $\mathrm{S}$. Int., colon, and kidney. One transcript with a length of $1.8 \mathrm{~kb}$ was detected only in the small intestine. In the bottom part, the pattern of methylene blue staining of the rRNA is presented.

sented in Figure 5B. Position "a" is mainly occupied by hydrophobic residues, positions "b" by glutamine hydrophobic residues, positions "c" and "d" by positively charged residues, positions "e" by hydrophilic neutral residues, and positions " $\mathrm{f}$ " and " $\mathrm{g}$ " by negatively charged residues.

The C-terminal region of the enterocytin, from Ala 226 to the C-terminus amino-acid, Leu 383, constitutes a highly conserved B30.2-like domain (framed in Fig. 5) (Henry et al., 1998). This domain has been identified in several proteins, but its function has not yet been determined. Phylogenetic tree analysis with B30.2 domains, as taxonomic unit, of various proteins (Fig. 5C) showed that the enterocytin and the enterophilin form a monophylogenetic group. In addition, Blast comparisons (Tatusova and Madden, 1999) performed on the enterocytin sequence show the most important similarity with guinea pig enterophilin, a recently identified protein family (Gassama-Diagne et al., 2001). Enterophilins are proteins with a leucine zipper, which have an N-terminus domain with a coiled-coil structure and a C-terminal B30.2-like domain. Sequence comparison between rabbit enterocytin and guinea pig enterophilins exhibit a $40 \%$ amino acid identity and an overall $60 \%$ similarity. The complete sequence of only one enterophilin with a molecular weight of $67 \mathrm{kDa}$ (enterophilin 1) is known so far (Gassama-Diagne et al., 2001). As shown in Figure 5A, the alignment of the enterocytin and enterophilin 1 started from Tyr 133 of enterophilin 1. There is only $27 \%$ amino acid identity between the enterocytin and enterophilin N-terminal coiled-coil region, whereas $64 \%$ amino acid identity are observed between enterophilin 1 and enterophilin 2L (GenBank accession number $\mathrm{AF} 126831$ ). In the case of the B30.2-like domains, there is a higher level of identity (59\%) between the enterocytin and enterophilin, but these percentages are much 
lower than the $91 \%$ amino acid identity found to exist between the B30.2-like domains of the two enterophilins. In the other hand, $75 \%$ amino acid identity were generally observed when the B30.2-like domains of orthologous proteins such as human and mouse $52 \mathrm{kDa}$ $\mathrm{Ag}$, human and rabbit pyrin, and human and mouse butyrophilin were compared. In view of these results, it is concluded that the similarity between rabbit enterocytin and guinea pig enterophilins is too weak to qualify these proteins as possible orthologous.

\section{Partial characterization of E6.1 and $2 \mathrm{C} 5 \mathrm{mAb}$ epitopes}

To confirm that both E6.1 and 2C5 mAbs recognize the enterocytin protein encoded by the isolated cDNA, we performed overexpression of this cDNA in Cos cells. In cells transfected, the expressed Myc-Enterocytin is recognized by $\mathrm{E} 6.1$ and $2 \mathrm{C} 5 \mathrm{mAbs}$ in immunofluorescence assays, as shown in Figure 6A. A similar subcellular distribution is obtained in Cos cells with anti-Myc, E6.1 and 2C5 antibodies. 2C5 mAbs also recognizes the Myc fusion protein in Western-blot analysis of transfected-cell extract (Fig. 6B). Consequently, E6.1 and 2C5 mAb recognize the same protein, the enterocytin, which is coded by the isolated cDNA. In addition, to map E6.1 and 2C5 mAb epitopes, Cos cells were transfected with different Myc-cDNA constructs encoding for the full enterocytin (Myc-Entc), the coiled-coil (Myc-CC), and the B30.2-like domain (Myc-B30.2). In the immunofluorescence analysis, 2C5 and E6.1 mAbs recognize the full-length protein (Fig. 6A). We also show that E6.1 mAb is unable to recognize either isolated $\mathrm{N}$-terminus coiled-coil or B30.2 domains. By contrast, Western-blot analysis showed that $2 \mathrm{C} 5 \mathrm{mAb}$ is able to detect the $27 \mathrm{kDa} \mathrm{Myc}-\mathrm{CC}$ domain but not the $22 \mathrm{kDa}$ Myc-B30.2 domain (Fig. 6B). These results show that $\mathrm{E} 6.1 \mathrm{mAb}$ epitope is conformational and is present only in the complete protein

A

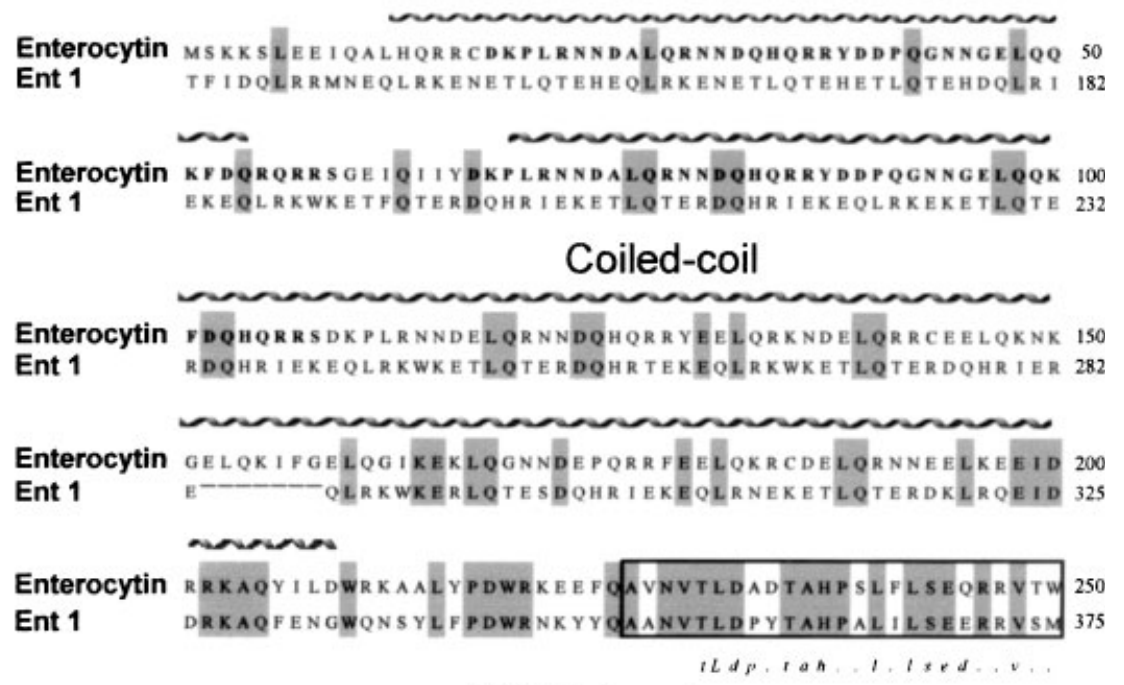

B30.2 domain
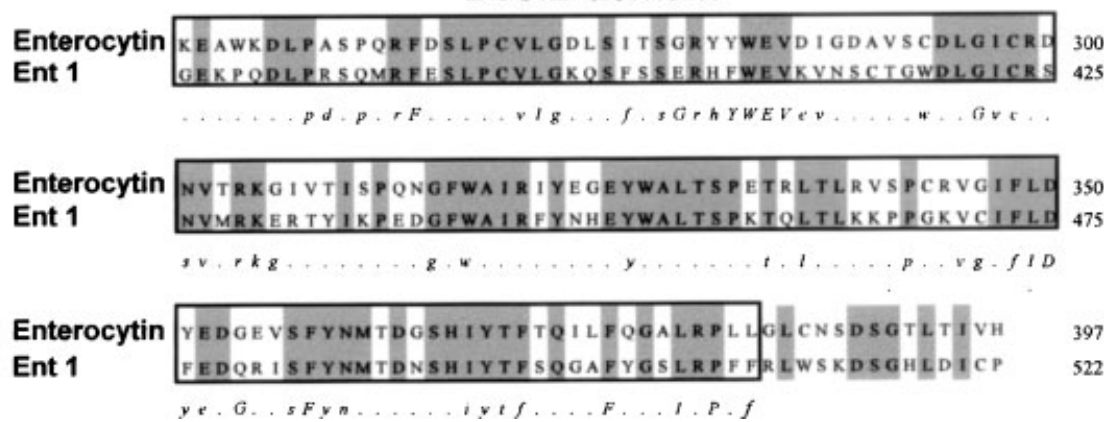

Fig. 5. A: Amino acid alignment of rabbit Enterocytin and guinea pig enterophilin 1 (Ent 1) (Gassama-Diagne et al., 2001). Sequences were aligned using the BLASTN and BLASTX network servers at NCBI. Light gray boxes indicate the existence of identical amino acid residues between the two proteins. Note that the first 132 amino acids of Ent 1 are not given here. The N-terminal sequence with a coiled-coil structure is represented by a spiral stretched length-wise. The two portions of Enterocytin sequence in the N-terminal domain shown in heavy type constitute two identical repeat units (from Asp18 to Ser 59 and from Asp 67 to Ser 108), apart form one residue underlined, by unity, in positions 55 and 104. The B30.2-like domain is framed and the residues in the consensus sequence of the B30.2 domains (Henry et al., 1998) are given, below the sequences, in italics. B: Helical wheel diagram of the Enterocytin sequence from His 13 to Leu 208 residues, which form a coiled-coil structure. -, indicates an interruption in the coiled-coil structure from Pro 55 to Lys 68 C: Consensus phylogenetic tree of B30.2-like domains of the protein family bearing this domain. The tree is shown in the form of a phylogram. Protein names are followed by the name of species in which these proteins have been isolated, and then by their accession numbers to the National Center for Biotechnology Information database. 
B

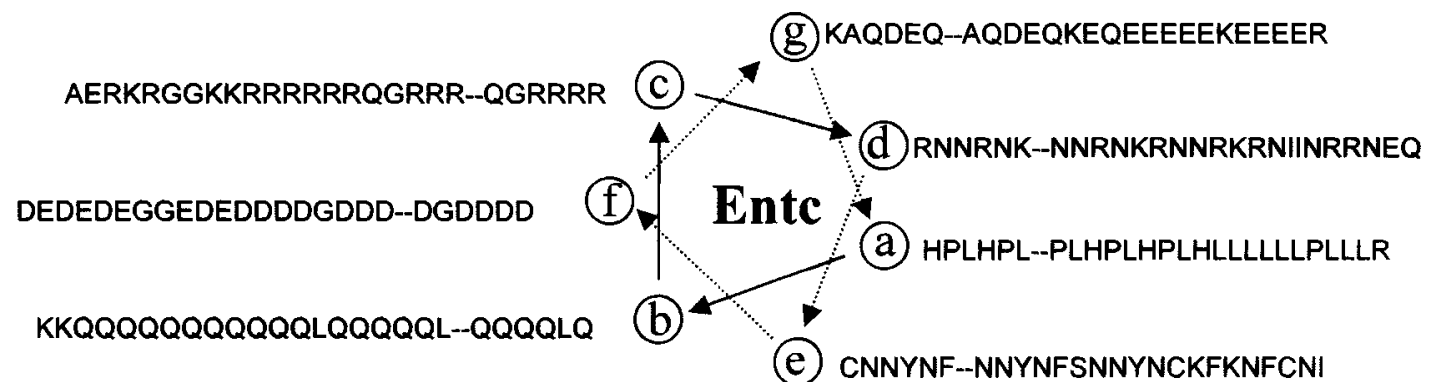

C

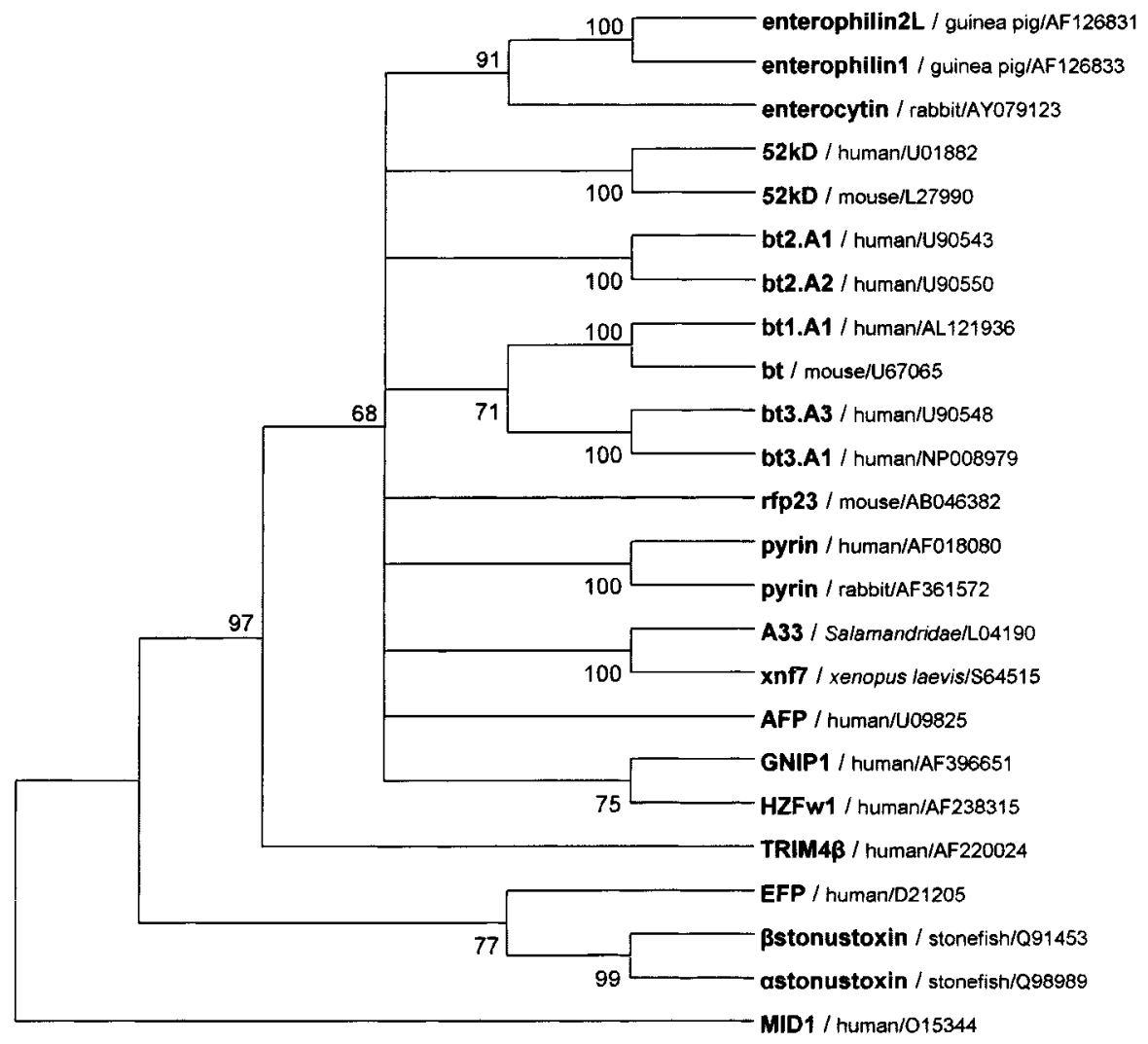

Fig. 5. (Continued)

whereas $2 \mathrm{C} 5 \mathrm{mAb}$ epitope is carried by the coiled-coil structure of the enterocytin.

\section{Dimerization of the enterocytin}

The coiled-coil structure has been described as a possible dimerization or oligomerization motif (Lupas, 1996; Burkhard et al., 2001). To test that the enterocytin is able to dimerize, we cotransfected Cos- 1 cells with constructs tagged with either Myc or EGFP epitope tags (Fig. 7A). Following immunoprecipitation with an antiMyc antibody and Western-blot using an anti-EGFP antibody, we observe that EGFP-Enterocytin is coimmunoprecipitated with Myc-Enterocytin (Fig. 7B, lane 4) and Myc-coiled-coil Enterocytin (Fig. 7B, lane 5). $\mathrm{N}$-terminal deletion of the coiled-coil region of MycEnterocytin abolishes its ability to dimerize with the full-length EGFP-Enterocytin protein (Fig. 7B, lane 6). These data demonstrate that the enterocytin is able to homodimerize via its coiled-coil $\mathrm{N}$-terminus region.

\section{DISCUSSION}

In this study, we identified a new protein named enterocytin, which belongs to the family of proteins containing a B30.2-like domain. The enterocytin is exclusively expressed by absorptive cells in the small intestine, and its level of expression increases along the 
A

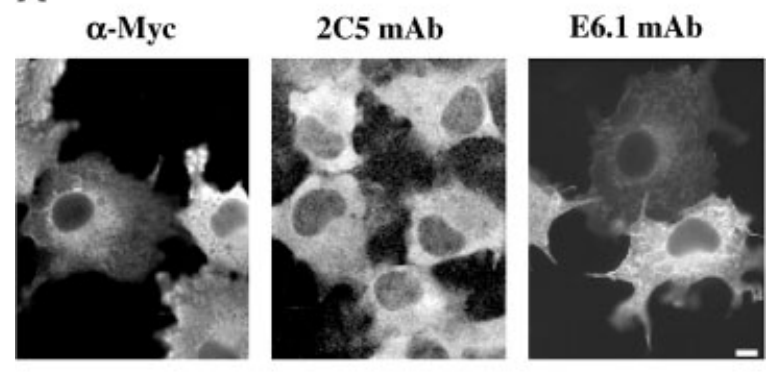

B

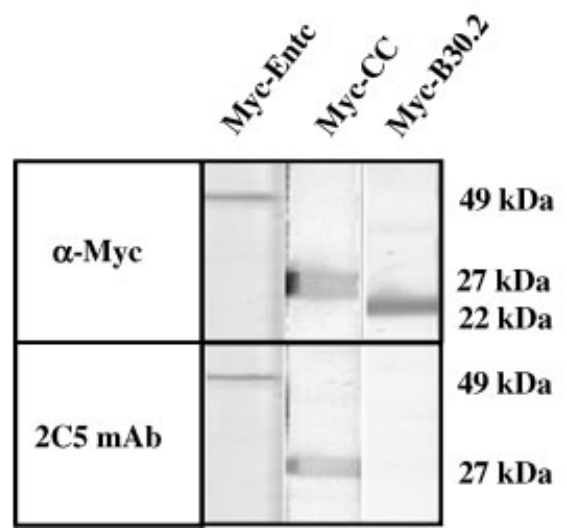

Fig. 6. A: Pattern of immunofluorescence of Cos cells transfected with Myc-Enterocytin-cDNA (Myc-Entc) and revealed by anti-Myc $\mathrm{mAb}$ or $2 \mathrm{C} 5 \mathrm{mAb}$ or E6.1mAb. B: Western blot analysis of $10 \mu \mathrm{g}$ of Cos cell extract transfected with Myc-Enterocytin (Myc-Entc) or Myc-coiled-coil (Myc-CC) or Myc-B30.2-like (Myc-B30.2) Enterocytin domains with anti-Myc $(\alpha-\mathrm{Myc})$ or $2 \mathrm{C} 5 \mathrm{mAbs}$, as described in the immunoblotting experiments section of immunoprecipitation and immunoblotting experiments in Materials and Methods.

crypt-villus axis. The enterocytin is therefore an efficient marker of enterocytic differentiation. This $47 \mathrm{kDa}$ protein consists of two parts, a N-terminus region arranged in a coiled-coil structure and a C-terminal B30.2-like domain. Blast comparison of enterocytin sequence show that the greatest similarity is observed with guinea pig enterophilin 1 , a recently identified protein with a molecular weight of $67 \mathrm{kDa}$ (GassamaDiagne et al., 2001). Enterophilin 1 also displays a coiled-coil N-terminal domain followed by a C-terminal B30.2-like domain, however, its tissular distribution is not limited to the absorptive cells of the small intestine (Gassama-Diagne et al., 2001). Gassama-Diagne et al. showed that Caco2 cells express a $67 \mathrm{kDa}$ enterophilin. In this article, we establish that these cells also express a $47 \mathrm{kDa}$ enterocytin. This co-expression show clearly that enterocytin and enterophilins are not orthologous proteins.

The original B30.2 domain was identified by Vernet et al. (1993). During a search for novel coding sequences within the human $\mathrm{MHC}$ class I region, these authors discovered an exon (named B30.2) coding for a conserved peptide present in several proteins, and they proposed to call this exon the B30.2-like domain.
A

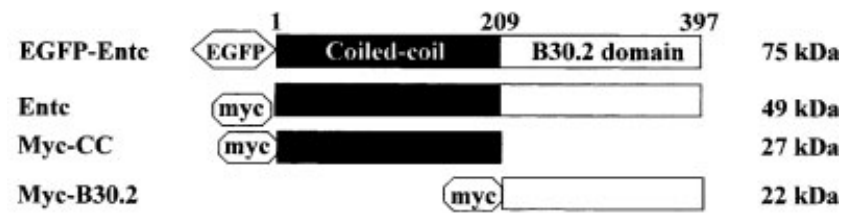

B

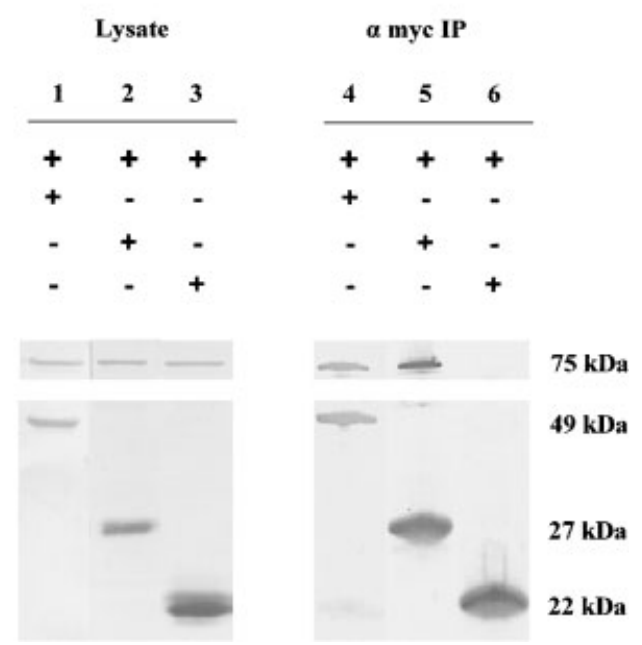

Fig. 7. A: Constructs used for the transfection of Cos cells. B: Western-blot analysis of the total lysate of transfected cells (lanes 1, 2, and 3) and that of immunoprecipitates obtained with anti-Myc mAb ( $\alpha$-Myc IP) (lanes 4, 5, and 6). Immunodetection of tagged proteins was carried out with either anti-EGFP mAb ( $\alpha$-EGFP) or anti-Myc $(\alpha-\mathrm{Myc})$. Transfected constructs used by experiments are indicated by the + sign

Given the presence of this 170 amino acid globular domain in the C-terminus part of the protein, these proteins can be classified in the same family consisting of three subgroups differing in their N-terminal regions (Henry et al., 1997, 1998). Along with enterophilins and the newly identified isoforms GNIP2 and GNIP3 of glycogenin interacting proteins (Skurat et al., 2002), the enterocytin belongs to a new subgroup in which the N-terminal part forms a coiled-coil structure. We have demonstrated that at least two molecules of enterocytin interact via their coiled-coil domain. Although the functional role of this oligomerization still remains to be studied, it certainly conveys on the protein some functional advantages (Engel and Kammerer, 2000).

Recently B30.2-like protein binding partners have been described indicating some putative roles (Torok and Etkin, 2001). For exemple, the B30.2-like cytoplasmic domain of butyrophillin (a transmembrane protein present in milk fat globule membrane) has been found to be associated with xanthine dehydrogenase/oxidase in mammary epithelial cells suggesting a role in milk lipid secretion (Ishii et al., 1995; McManaman et al., 2002). On the other hand, the B30.2-like domain of pyrin 
used as a bait in a yeast two-hybrid screen identified as an interactor the Golgi transporter (P/M-IP1). Interestingly, this interaction was shown impaired by mutations in B30.2-like domain in patients with FMF (Chen et al., 2000). In the autoimmune Sjogren's syndrome/systemic lupus erythematosus, interactions between the B30.2like domain of Ro52 and human immunoglobulins were detected (Rhodes et al., 2002). An other B30.2 containing protein, RFPL4, was described to interact with several proteins involved in the ubiquitin-proteasome system. RFLP4 appeared to target the cell cycle regulator Cyclin B1 for proteasomal degradation (Suzumori et al., 2003). Based on these results, the different partners of the B30.2-like domain seem specific of each B30.2-like containing protein and show that these proteins are involved in many different functions. However, the fact that pathologies such as FMF (Delpech and Grateau, 2001; Orbach and Ben-Chetrit, 2001) and Opitz syndrome (Quaderi et al., 1997) are due to mutations in the B30.2like domain of human pyrin and $M I D 1$ genes, respectively, points to the biological importance of this domain. Future studies on enterocytin B30.2 domain interactors will help to delineate the function of this protein.

The expression of the enterocytin was studied in immunofluorescence assays along the crypto-villar axis with E6.1 and 2C5 mAbs: enterocytin is detected at the top of the crypts and also observed in the terminal web with both monoclonal antibodies. Along the villi as in the crypts, the $2 \mathrm{C} 5 \mathrm{mAb}$ reacts exclusively with the terminal web of mature enterocytes, whereas E6.1 mAb labels not only the terminal web of these cells but also their plasma membrane and their nuclear membrane. The 2C5 non-conformational epitope located in the coiled-coil N-terminal part of the protein seems to be masked when the enterocytin is located in the lateral plasma or nuclear membrane. The differences in the accessibility of this epitope in various subcellular compartments may be explained by the state of oligomerization of the enterocytin, its association with other proteins or some post-translational modifications. In support of this hypothesis, our biochemical results (immunoprecipitations, expression cloning, transfection studies) demonstrate that both, E6.1 and 2C5 mAbs specifically recognize the enterocytin.

Interestingly, 2C5 mAb cross-reacts with a human $47 \mathrm{kDa}$ protein detected only in the small intestine and moreover located in the terminal web of mature human enterocytes. These data suggest that the human orthologous of rabbit enterocytin has the same molecular weight and displays an identical expression pattern. The 2C5 mAb assays also showed that human enterocytin is expressed in Caco 2 cells and that its polarized location in the terminal web depends on the state of differentiation of these cells in an "enterocyte-like" phenotype. The presence of endogenous enterocytin in Caco 2 cells will enable us to investigate its function and to identify its partners.

In conclusion, we have characterized a new enterocytic marker bearing a B30.2 domain. The terminal web localization of the enterocytin suggests that it may be involved in enterocytic polarization or differentiation mechanisms, as well as in the maintenance of the cellular architecture in the intestinal epithelium.

\section{ACKNOWLEDGMENTS}

We thank Dr. Claude Thomas (centre hospitalier de Digne-Les-Bains) and Dr. Marc Barthet (Hopital Nord, Marseille) for providing of human tissues. We also thank Dr. Pierre Pontarotti (EA Biodiversité, Phylogenomics Laboratory, Université d'Aix Marseille I, Marseille, France) for helpful discussion about the growing family of B30.2-like domain proteins and the construction of these B30.2-like domain phylogenetic tree. We also thank Dr. Suzanne Maroux for encouragement, advice, and critical reading of the manuscript. We also thank Dr. Jessica Blanc for correcting the English text.

\section{LITERATURE CITED}

Athman R, Louvard D, Robine S. 2002. The epithelial cell cytoskeleton and intracellular trafficking. III. How is villin involved in the actin cytoskeleton dynamics in intestinal cells? Am J Physiol Gastrointest Liver Physiol 283(3):G496-G502.

Beck F. 2002. Homeobox genes in gut development. Gut 51(3):450454.

Booth C, Potten CS. 2000. Gut instincts: Thoughts on intestinal epithelial stem cells. J Clin Invest 105(11):1493-1499.

Borg JP, Ooi J, Levy E, Margolis B. 1996. The phosphotyrosine interaction domains of X11 and FE65 bind to distinct sites on the YENPTY motif of amyloid precursor protein. Mol Cell Biol 16(11): 6229-6241.

Burkhard P, Stetefeld J, Strelkov SV. 2001. Coiled coils: A highly versatile protein folding motif. Trends Cell Biol 11(2):82-88.

Calvert R, Pothier P. 1990. Migration of fetal intestinal intervillous cells in neonatal mice. Anat Rec 227(2):199-206.

Chantret I, Barbat A, Dussaulx E, Brattain MG, Zweibaum A. 1988 Epithelial polarity, villin expression, and enterocytic differentiation of cultured human colon carcinoma cells: A survey of twenty cell lines. Cancer Res 48(7):1936-1942.

Chen X, Bykhovskaya Y, Tidow N, Hamon M, Bercovitz Z, Spirina O Fischel-Ghodsian N. 2000. The familial mediterranean fever protein interacts and colocalizes with a putative Golgi transporter. Proc Soc Exp Biol Med 224(1):32-40.

Christiansen K, Carlsen J. 1981. Microvillus membrane vesicles from pig small intestine. Purity and lipid composition. Biochim Biophys Acta 647(2):188-195.

Clatworthy JP, Subramanian V. 2001. Stem cells and the regulation of proliferation, differentiation, and patterning in the intestinal epithelium: Emerging insights from gene expression patterns, transgenic, and gene ablation studies. Mech Dev 101(1-2):3-9.

Combet C, Blanchet C, Geourjon C, Deleage G. 2000. NPS@: Network protein sequence analysis. Trends Biochem Sci 25(3):147-150.

Cox TC, Allen LR, Cox LL, Hopwood B, Goodwin B, Haan E, Suthers GK. 2000. New mutations in MID1 provide support for loss of function as the cause of X-linked Opitz syndrome. Hum Mol Genet 9(17):2553-2562.

Delpech M, Grateau G. 2001. Genetically determined recurrent fevers. Curr Opin Immunol 13(5):539-542.

Engel J, Kammerer RA. 2000. What are oligomerization domains good for? Matrix Biol 19(4):283-288

Feracci H, Bernadac A, Gorvel JP, Maroux S. 1982. Localization by immunofluorescence and histochemical labeling of aminopeptidase $\mathrm{N}$ in relation to its biosynthesis in rabbit and pig enterocytes. Gastroenterology 82(2):317-324.

Feracci H, Rigal A, Maroux S. 1985. Biosynthesis and intracellular pool of aminopeptidase $\mathrm{N}$ in rabbit enterocytes. J Membr Biol 83(12):139-146.

Freund JN, Domon-Dell C, Kedinger M, Duluc I. 1998. The $C d x-1$ and $C d x-2$ homeobox genes in the intestine. Biochem Cell Biol 76(6):957-969.

Friederich E, Pringault E, Arpin M, Louvard D. 1990. From the structure to the function of villin, an actin-binding protein of the brush border. Bioessays 12(9):403-408.

Galand G. 1989. Brush border membrane sucrase-isomaltase, maltase-glucoamylase, and trehalase in mammals. Comparative development, effects of glucocorticoids, molecular mechanisms, and phylogenetic implications. Comp Biochem Physiol B 94(1):1-11.

Gassama-Diagne A, Hullin-Matsuda F, Li RY, Nauze M, Ragab A, Pons V, Delagebeaudeuf C, Simon MF, Fauvel J, Chap H. 2001. Enterophilins, a new family of leucine zipper proteins bearing a 
b30.2 domain and associated with enterocyte differentiation. J Biol Chem 276(21):18352-18360.

Gorvel JP, Rigal A, Olive D, Mawas C, Maroux S. 1986. Identification of an early expressed marker of the luminal membrane of rabbit small intestinal columnar cells. Presence of a homologous antigen in kidney proximal tubules and glomeruli. Biol Cell 56(2):121-126.

Gorvel JP, Mishal Z, Maroux S. 1988. Characterization of intestinal membrane vesicles with flow cytometry. Prog Clin Biol Res 270: 195-209.

Green J, Griffiths G, Louvard D, Quinn P, Warren G. 1981. Passage of viral membrane proteins through the Golgi complex. J Mol Biol 152(4):663-698

Henry J, Ribouchon MT, Offer C, Pontarotti P. 1997. B30.2-like domain proteins: A growing family. Biochem Biophys Res Commun 235(1):162-165.

Henry J, Mather IH, McDermott MF, Pontarotti P. 1998. B30.2-like domain proteins: Update and new insights into a rapidly expanding family of proteins. Mol Biol Evol 15(12):1696-1705.

Hertzel AV, Bernlohr DA. 2000. The mammalian fatty acid-binding protein multigene family: Molecular and genetic insights into function. Trends Endocrinol Metab 11(5):175-180.

Ishii T, Aoki N, Noda A, Adachi T, Nakamura R, Matsuda T. 1995. Carboxy-terminal cytoplasmic domain of mouse butyrophilin specifically associates with a $150-\mathrm{kDa}$ protein of mammary epithelial cells and milk fat globule membrane. Biochim Biophys Acta 1245(3):285-292.

Kawai K, Fujita M, Nakao M. 1974. Lipid components of two different regions of an intestinal epithelial cell membrane of mouse. Biochim Biophys Acta 369(2):222-233.

Kenny AJ, Maroux S. 1982. Topology of microvillar membrance hydrolases of kidney and intestine. Physiol Rev 62(1):91-128.

Kumar S, Tamura K, Jakobsen IB, Nei M. 2001. MEGA2: Molecular evolutionary genetics analysis software. Bioinformatics 17(12): $1244-1245$.

Laemmli UK. 1970. Cleavage of structural proteins during the assembly of the head of bacteriophage T4. Nature 227(259):680685.

Lupas A. 1996. Coiled coils: New structures and new functions. Trends Biochem Sci 21(10):375-382.

Marshman E, Booth C, Potten CS. 2002. The intestinal epithelial stem cell. Bioessays 24(1):91-98

Massey D, Feracci H, Gorvel JP, Rigal A, Soulie JM, Maroux S. 1987. Evidence for the transit of aminopeptidase $\mathrm{N}$ through the basolateral membrane before it reaches the brush border of enterocytes. J Membr Biol 96(1):19-25.

Massey D, Traverso V, Maroux S. 1991. Lipocortin IV is a basolateral cytoskeleton constituent of rabbit enterocytes. J Biol Chem 266(5): $3125-3130$

McManaman JL, Palmer CA, Wright RM, Neville MC. 2002 Functional regulation of xanthine oxidoreductase expression and localization in the mouse mammary gland: Evidence of a role in lipid secretion. J Physiol 545(Pt 2):567-579

Moktari S, Feracci H, Gorvel JP, Mishal Z, Rigal A, Maroux S. 1986. Subcellular fractionation and subcellular localization of aminopeptidase $\mathrm{N}$ in the rabbit enterocytes. J Membr Biol 89(1):53-63.
Naim HY. 2001. Molecular and cellular aspects and regulation of intestinal lactase-phlorizin hydrolase. Histol Histopathol 16(2): $553-561$.

Orbach H, Ben-Chetrit E. 2001. Familial mediterranean fever-A review and update. Minerva Med 92(6):421-430.

Pringault E, Robine S, Louvard D. 1991. Structure of the human villin gene. Proc Natl Acad Sci USA 88(23):10811-10815.

Quaderi NA, Schweiger S, Gaudenz K, Franco B, Rugarli EI, Berger W, Feldman GJ, Volta M, Andolfi G, Gilgenkrantz S, Marion RW, Hennekam RC, Opitz JM, Muenke M, Ropers HH, Ballabio A. 1997. Opitz G/BBB syndrome, a defect of midline development, is due to mutations in a new RING finger gene on Xp22. Nat Genet 17(3) $285-291$.

Rajendran VM, Binder HJ. 2000. Characterization and molecular localization of anion transporters in colonic epithelial cells. Ann NY Acad Sci 915:15-29.

Rhodes DA, Ihrke G, Reinicke AT, Malcherek G, Towey M, Isenberg DA, Trowsdale J. 2002. The 52000 MW Ro/SS-A autoantigen in Sjogren's syndrome/systemic lupus erythematosus (Ro52) is an interferon-gamma inducible tripartite motif protein associated with membrane proximal structures. Immunology 106(2):246-256.

Saitou N, Nei M. 1987. The neighbor-joining method: A new method for reconstructing phylogenetic trees. Mol Biol Evol 4(4):406-425.

Salas PJ, Rodriguez ML, Viciana AL, Vega-Salas DE, Hauri HP. 1997. The apical submembrane cytoskeleton participates in the organization of the apical pole in epithelial cells. J Cell Biol 137(2):359-375.

Skurat AV, Dietrich AD, Zhai L, Roach PJ. 2002. GNIP, a novel protein that binds and activates glycogenin, the self-glucosylating initiator of glycogen biosynthesis. J Biol Chem 277(22):1933119338.

Storch J, Thumser AE. 2000. The fatty acid transport function of fatty acid-binding proteins. Biochim Biophys Acta 1486(1):28-44.

Suzumori N, Burns KH, Yan W, Matzuk MM. 2003. RFPL4 interacts with oocyte proteins of the ubiquitin-proteasome degradation pathway. Proc Natl Acad Sci USA 100(2):550-555.

Tatusova TA, Madden TL. 1999. BLAST 2 sequences, a new tool for comparing protein and nucleotide sequences. FEMS Microbiol Lett 174(2):247-250.

Thompson JD, Higgins DG, Gibson TJ. 1994. CLUSTAL W: Improving the sensitivity of progressive multiple sequence alignment through sequence weighting, position-specific gap penalties, and weight matrix choice. Nucleic Acids Res 22(22):4673-4680.

Torok M, Etkin LD. 2001. Two B or not two B? Overview of the rapidly expanding B-box family of proteins. Differentiation 67(3): $63-71$.

Vernet C, Boretto J, Mattei MG, Takahashi M, Jack LJ, Mather IH, Rouquier S, Pontarotti P. 1993. Evolutionary study of multigenic families mapping close to the human MHC class I region. J Mol Evol 37(6):600-612.

Wilm M. 2000. Mass spectrometric analysis of proteins. Adv Protein Chem 54:1-30.

Wong MH, Saam JR, Stappenbeck TS, Rexer CH, Gordon JI. 2000 Genetic mosaic analysis based on Cre recombinase and navigated laser capture microdissection. Proc Natl Acad Sci USA 97(23): 12601-12606. 